\title{
BIOPOTENTIALS OF SEAWEEDS COLLECTED FROM SOUTHWEST COAST OF INDIA
}

\author{
Aseer Manilal \\ Department of Microbiology, Bharathidasan University, Tiruchirappalli 620 024, India. \\ Sugathan Sujith \\ Department of Microbiology, Bharathidasan University, Tiruchirappalli 620 024, India. \\ George Seghal Kiran \\ Department of Biotechnology, Bharathidasan University, Tiruchirappalli 620 024, India. \\ Joseph Selvin \\ Department of Microbiology, Bharathidasan University, Tiruchirappalli 620 024, India., selvinj@rediffmail.com \\ Chippu Shakir \\ Department of Microbiology, Bharathidasan University, Tiruchirappalli 620 024, India.
}

See next page for additional authors

Follow this and additional works at: https://jmstt.ntou.edu.tw/journal

Part of the Aquaculture and Fisheries Commons

\section{Recommended Citation}

Manilal, Aseer; Sujith, Sugathan; Kiran, George Seghal; Selvin, Joseph; Shakir, Chippu; Gandhimathi, Ramakrishnan; and Panikkar, Mamkoottathil Velayudhan Nataraja (2009) "BIOPOTENTIALS OF SEAWEEDS COLLECTED FROM SOUTHWEST COAST OF INDIA," Journal of Marine Science and Technology. Vol. 17: Iss. 1, Article 10. DOI: $10.51400 / 2709-6998.1979$

Available at: https://jmstt.ntou.edu.tw/journal/vol17/iss1/10

This Research Article is brought to you for free and open access by Journal of Marine Science and Technology. It has been accepted for inclusion in Journal of Marine Science and Technology by an authorized editor of Journal of Marine Science and Technology. 


\section{BIOPOTENTIALS OF SEAWEEDS COLLECTED FROM SOUTHWEST COAST OF INDIA}

\section{Acknowledgements}

We wish to thank Dr. A. P. Lipton, Professor and Head, Department of Marine Biotectnology, CMST, Rajakkamagalam, Nagercoil for valuable suggestions throughout this study. Thanks are extending to Dr. M. V. N. Panikkar, Dr. Priyadharsan D. Prasad, R. Rajagopal, Dr. S. Sulekha, C. K. Thankachy and Dr. M. Jayakumari Professors, Department of Biotechnology, Botany and Zoology, Sree Narayana College, Kollam, Kerala for encouragements. The first author AM and SS is gratefully acknowledged to DBT for providing JRF. This paper is a part of the DBT project (BT/PR8064/AAQ/03/290/2006).

\section{Authors}

Aseer Manilal, Sugathan Sujith, George Seghal Kiran, Joseph Selvin, Chippu Shakir, Ramakrishnan Gandhimathi, and Mamkoottathil Velayudhan Nataraja Panikkar 


\title{
BIOPOTENTIALS OF SEAWEEDS COLLECTED FROM SOUTHWEST COAST OF INDIA
}

\author{
Aseer Manilal*, Sugathan Sujith*, George Seghal Kiran**, Joseph Selvin*, \\ Chippu Shakir*, Ramakrishnan Gandhimathi*, \\ and Mamkoottathil Velayudhan Nataraja Panikkar***
}

Key words: bioactive compounds, seaweed extract, brine shrimp bioassay, nematicidal, ichthyotoxic, larvicidal activity.

\begin{abstract}
Southwest coast of India is a unique marine habitat infested with diverse seaweeds. Therefore, the present study was initiated to explore bioactive potential of major seaweeds. Thirteen seaweeds belonging to three groups were collected from the coast was extracted in methanol:dichloromethane (1:1) and tested for different range of bioactivities including brine shrimp cytotoxicity, larvicidal, ichthyotoxic and nematicidal activities. It was found that out of 13 seaweeds extracts, Dictyota dichotoma and Hypnea pannosa showed lethal effect on root knot nematode Meloidogyne javanica. All 13 tested seaweeds invariably showed varied range of ichthyotoxicity particularly $D$. dichotoma, Valoniopsis pachynema and Acrosiphonia orientalis showed highest toxicity. Of the 13 seaweed extracts studied, A. orientalis, Padina tetrastromatica and Centeroceras clavulatum were most effective against second instar mosquito larvae but the activity of $P$. tetrastromatica was not restored in the third instar bioassay. A. orientalis exhibited a wide range of activities including brine shrimp cytotoxicity, antifeedant and larvicidal activity. The finding envisages that crude extracts of all seaweeds contained synergistic bioactivities which can be used for the production of potential biopesticides and novel pharmaceutical leads.
\end{abstract}

\section{INTRODUCTION}

Seaweeds are the extraordinary sustainable resources in the marine ecosystem which have been used as a source of food, feed and medicine. It was estimated that about $90 \%$ of the spe-

Paper submitted 11/13/07; accepted 03/17/08. Author for correspondence: Joseph Selvin (selvinj@ rediffmail.com).

* Department of Microbiology, Bharathidasan University, Tiruchirappalli 620 024, India.

** Department of Biotechnology, Bharathidasan University, Tiruchirappalli 620024 , India.

*** Department of Botany, Sree Narayana College, Kollam 691001, Kerala, India. cies of marine plant are algae and about $50 \%$ of the global photosynthesis is contributed from algae [10]. Approximately 841 species of marine algae found in both inter-tidal and deep water regions of the Indian coast [33]. A post-tsunami survey conducted along the peninsular coast India evidenced that the collection site of the present study (Kollam coast) flourished with highest diversity of seaweeds [28]. The tsunami affected peninsular coast of India flourished with 15 species of seaweeds belonging to 14 genera of Rhodophyta, 15 species to 9 genera of Phaeophyta and 15 species to 8 genera of Chlorophyta. India ranks first among all countries bordering the Indian Ocean ahead of Australia and South Africa in the number of recorded specific and intraspecific seaweed taxa [40]. These vast varieties of seaweeds were found to possess useful untapped biochemical compounds, which might be a potential source of drug leads in the future [23]. Until now more than 2400 marine natural products have been isolated from seaweeds of subtropical and tropical populations [31, 12]. These natural products, are known as secondary metabolites which posses a broad range of ecological interactions in marine life [21].

The inhibitory substances biosynthesized by the seaweeds were noted as early as in 1917 [18]. The first observation regarding antibiotic activities of seaweeds was reported by Pratt $e t$ al. [37]. Recent findings evidenced that seaweeds contained antibacterial [50], antiviral [43, 15], antifungal [47, 2], cytotoxic [47] and larvicidal potentials [48]. The secondary metabolites synthesized by seaweeds demonstrate a broad spectrum of bioactivity varying from neurologically active in humans to algicidal, nematicidal, insecticidal and ichthyotoxicity in lower form of animals [45]. In this background, the present study was initiated to explore the bioactive potential of major seaweeds infested along southwest coast of India as a potential source of marine bioprospecting.

\section{MATERIALS AND METHODS}

Seaweeds belonging to chlorophyta, phaeophyta and rhodophyta were collected in different season (April to September 2007) during the lowest tide of chart datum from the seaweed infested locations along southwest coast of India, Kollam $\left(08^{\circ} 54^{\prime} \mathrm{N} \& 76^{\circ} 38^{\prime} \mathrm{E}\right)$ and Varkala $\left(08^{\circ} 28^{\prime} \mathrm{N} \& 76^{\circ} 55^{\prime}\right.$ 
E) area. The study area, southwest coast comprising of numerous sandy beaches and irregularly distributed rocky substratum interspersed with sandy intertidal pools inhabited with a wide variety of marine algae [28]. The algae, which infested exclusively on the intertidal rocky and other substratum, were selected for the collection in order to avoid other algal contamination. These algae were collected using a metal scraper. Immediately after collection, they were washed in fresh seawater to remove the epiphytes, sand and other extraneous matter. After draining off the water, the algae were wiped with a blotting sheet and air-dried under shade. After completing the shade drying process, they were cut into small pieces and dried in an oven at $45^{\circ} \mathrm{C}$. Completely dried material was weighed and ground finely in a mechanical grinder.

\section{Extraction of Crude Bioactives}

For extraction of crude bioactives, $500 \mathrm{~g}$ of finely powdered algal material was refluxed three times in a 5 liter capacity round bottom flask in a water bath at $65^{\circ} \mathrm{C}$ for about $6 \mathrm{~h}$ using dichloromethane: methanol (1:1) as a binary azeotropic solvent [42]. The extracts were filtered and concentrated to recover the excess solvents in another distillation system. The concentrated extract (about 100ml) was again filtered through a Whatman no. 1 filter paper fitted with a Buchner funnel using suction pressure. Finally, it was reduced to thick oily natured crude extract in a rotary vacuum evaporator (Yamato) at $40^{\circ} \mathrm{C}$, collected in airtight plastic vials and stored in the refrigerator for further activity studies.

\section{Brine Shrimp Assay}

About $0.1 \mathrm{~g}$ of Artemia salina cysts was aerated in $1 \mathrm{~L}$ capacity glass cylinder (jar) containing filtered seawater. The air stone was placed in the bottom of the jar to ensure complete hydration of the cysts. After $24 \mathrm{~h}$, the newly hatched freeswimming pink-coloured nauplii were harvested from the bottom outlet. As the cyst capsules floated on the surface, this collection method ensured pure harvest of nauplii. The freshly hatched free-swimming nauplii were used for the bioassay. The assay system was prepared with $2 \mathrm{ml}$ of filtered seawater containing chosen concentration of extract in cavity blocks (Embryo cup). Parallel vehicle control (using $2 \%$ methanol) and negative control (without vehicle) wells also kept. In each, 20 nauplii were transferred and the setup was allowed to remain for $24 \mathrm{~h}$, under constant illumination. After $24 \mathrm{~h}$, the dead nauplii were counted with a hand lens. Based on the percent mortality, the $\mathrm{LD}_{50}$ of the test compound was determined using probit scale [55].

\section{In Vitro Nematicidal Activity}

Nematicidal activity was evaluated using juvenile nematodes of Meloidogyne javanica. Assay system was prepared with $2 \mathrm{ml}$ Milli Q water containing different concentrations of seaweed extracts $(1,2,3$ and $4 \mathrm{mg} / \mathrm{ml})$ in glass tubes. 10 juveniles of $M$. javanica were transferred in test, positive (with $2 \%$ methanol) and negative (without vehicle) control tubes. Each concentration had three replicates. Mortality was observed under a zoom streomicroscope after $24 \mathrm{~h}$ of exposure. The mortality percentage was converted into probit scale to determine the $\mathrm{LD}_{50}$ values.

\section{Ichthyotoxic Activity of Seaweeds}

Fingerlings $(1.5-2.0 \mathrm{~cm})$ of marine acclimated marine acclimated Danio aequipinnatus were used for evaluating the ichthyotoxic potential. Five fingerlings were introduced in each experimental and control glass bowls containing $1000 \mathrm{ml} \mathrm{sea-}$ water dissolved with chosen concentration of the extract. Immediate reflex changes and mortality were observed continuously for six hours and at $1 \mathrm{~h}$ interval for the next $12 \mathrm{~h}$. After 24 $\mathrm{h}$ of exposure, the number of dead and live fish was counted. The acute toxicological reflexes were observed and recorded.

\section{Larvicidal Activity of Seaweeds}

The persistence of larvicidal activity of various extracts was tested against the urban mosquito Culex quinquefasiatus using standard bioassay protocol. Eggs of $C$. quinquefasiatus were obtained from drainage system. Eggs were placed in clean water and kept at room temperature for hatching. Larval development was monitored for seven days. The second and third stage larvae were collected at the tip of a pasture pipette and placed in cotton bud to remove excess water and transferred to the test vial (ten/ vial). The larval mortality was observed using various concentrations of seaweed extracts $(100,200,300,400 \& 500 \mu \mathrm{g} / \mathrm{ml})$ including positive (with $2 \%$ methanol) and negative controls (without vehicle). The number of larvae surviving after $24 \mathrm{~h}$ of exposure was recorded. All the experiments were repeated six times to validate the findings statistically.

\section{RESULTS AND DISCUSSION}

\section{Organisms and Seasonality}

Seaweeds belong to Chlorophyta (6 species), Phaeophyta ( 3 species) and Rhodophyta (4 species) were identified after recent classification [44]. The species of division chlorophyta are collected during post monsoon season (July to September) and are distributed in the rocky outcrops of intertidal zone. Among the six members of chlorophyta, Ulva fasciata, A. orientalis, Chaetomorpha antennina and Enteromorpha intestanalis were dominated in this area. While the samples of phaeophyta were distributed widely in subtidal zone and their abundance was observed during November to April. D. dichotoma was the dominant brown alga infested along the coast. The red algae were observed in different habitats of upper intertidal, intertidal and subtidal zones during April onwards. Extensive bed of Gracilaria corticata was found even in off-season. Plants of $C$. clavulatum were quite common in this period. The dry weight and wet weight ratio varied according to the biogeographical factors and its extraction yield differ from species to species of different algal groups [26]. Data for wet weight, dry weight and yield per gram of seaweeds were presented in Table 1. 
Table 1. Extract yield of seaweeds collected from southwest coast.

\begin{tabular}{|l|l|c|c|c|}
\hline \multirow{5}{*}{ Division } & Species & Wet wt. (g) & Dry wt. (g) & Yield (g/dry wt.) \\
\hline \multirow{5}{*}{ Chlorophyta } & $\begin{array}{l}\text { Valoniopsis pachynema (G. Martens) } \\
\text { Børgesen }\end{array}$ & 4300 & 648 & 0.0629 \\
\cline { 2 - 5 } & $\begin{array}{l}\text { Chaetomorpha antennina (Bory de } \\
\text { Saint-Vincent) Kützing }\end{array}$ & 3080 & 719 & 0.088 \\
\cline { 2 - 5 } & $\begin{array}{l}\text { Enteromorpha intestinalis (Linnaeus) Nees } \\
\text { var. crispa } \text { (Roth) Greville }\end{array}$ & 2800 & 861 & 0.11 \\
\cline { 2 - 5 } Phaeophyta & Acrosiphonia orientalis (J. Agardh) P. Silva. & 5600 & 1240 & 0.082 \\
\cline { 2 - 5 } & Ulva fasciata Delile & 3400 & 558 & 0.053 \\
\cline { 2 - 5 } & Caulerpa racemosa (Forsskål) J. Agardh & 5900 & 813 & 0.09 \\
\cline { 2 - 5 } & Dictyota dichotoma (Hudson) Lamouroux. & 6000 & 593 & 0.1904 \\
\cline { 2 - 5 } & $\begin{array}{l}\text { Padina tetrastromatica Hauck } \\
\text { \& Thoospora bicanaliculata } \text { V. Krishnamurthy }\end{array}$ & 4400 & 568 & 0.085 \\
\hline & Gracilaria corticata (J. Agardh) J. Agardh & 7500 & 1186 & 0.07 \\
\cline { 2 - 5 } & Hypnea pannosa J. Agardh & 5800 & 528 & 0.248 \\
\cline { 2 - 5 } & $\begin{array}{l}\text { Centroceras clavulatum } \text { (C. Agardh) } \\
\text { Montagne }\end{array}$ & 4500 & 751 & 0.027 \\
\cline { 2 - 5 } & Cheilosporum spectabile Harvey ex Grunow & 3000 & 1670 & 0.039 \\
\hline
\end{tabular}

\section{Brine Shrimp Cytotoxicity of Seaweeds}

Of the 13 seaweed extracts examined for brine shrimp cytotoxicity, $A$. orientalis was found to be highly effective (LD $50=$ $125.8 \mu \mathrm{g} / \mathrm{ml}$ ) whereas $V$. pachynema, E. intestanalis, and Caulerpa racemosa showed considerable action and their LD50 value was below $250 \mu \mathrm{g} / \mathrm{ml}$ and for other extracts LD 50 value occurred above $250 \mu \mathrm{g} / \mathrm{ml}$. (Table 2). Brine shrimp cytotoxicity test has been used as a bioassay for a variety of toxic substances [30] and it can be extrapolated for cell-line toxicity and anti tumour activity. Cytotoxic property by plant material is due to the presence of antitumour compounds [3]. Many of the secondary metabolites biosynthesized by the marine plants are well known for there cytotoxic property. Fucoidans exhibit antitumour, anticancer, antimetastatic and fibrinolytic properties in mice [7]. Religa et al. [38] reported that fucoidans also reduces cell proliferation. Stypoldione, isolated from Stypodium $s p$. was a potent cytotoxic metabolite, which halts mitotic spindle formation [16, 25]. Palermo et al. [34] reported a compound, Condriamide A from Chondria sp. exhibited cytotoxicity towards human nasopharyngeal and colorectan cancer cells. Terpenes from seaweeds displayed wide spectrum of cytotoxic and antitumour activities [53, 9]. Caulerpenyne from Caulerpa sp. showed its bioactivity against human cell lines and having anticancer, antitumour and antiproliferating properties [14, 35, 4]. Urones et al. [51] acknowledged two compound showing antitumour properties isolated from Cystophora sp. are meroterpenes and usneoidone. The present findings suggested that $A$. orientalis could be explored for prospecting novel anticancer leads.

\section{Nematicidal Activity}

It was found that out of 13 seaweeds extracts D. dichotoma and $\mathrm{H}$. pannosa had lethal effects and killed $50 \%$ of nematodes when their LD50 value were 1.23 and $1.25 \mathrm{mg} / \mathrm{ml}$ respectively, whereas the extracts of C. antennina, C. racemosa, Cheilosporum spectabile and V. pachynema showed LD50 value above $2 \mathrm{mg} / \mathrm{ml}$ (Table 3). Root knot nematode are distributed worldwide, infecting wide range of plants including major crops and caused considerable economic loss [41]. Throughout of the world, root knot nematode causes an average crop loss of 8 to $11 \%$ [27]. There are many early reports showing application of seaweed extracts can reduce the nematode infestation in plants $[8,57,58]$. Presence of cytokinins in seaweed extracts may be responsible for nematicidal activity [13]. According to Wu et al. [58] betaines of seaweed extracts can suppress the growth of nematodes. Terpenoid compounds in seaweeds known to have nematicidal activity [1]. Domoic acid isolated from Digenea simplex and Chondria armata displayed anthelminthic activity [22]. Considering the emerging issues pertaining to the use of chemical pesticides, suitable alternative resources and ecofriendly perspective are an urgent need of sustainable agriculture. The present finding brings out new insight in the development of ecofriendly biopesticides for the management of root-knot nematodes.

\section{Antifeedant Activity of Seaweeds}

In the present study, all 13 tested seaweeds showed varied range of ichthyotoxicity. Highest toxicity was observed in $D$. dichotoma, V. pachynema and A. orientalis. Among these, D. 
Table 2. Brine shrimp cytotoxicity of seaweeds.

\begin{tabular}{|c|c|c|c|c|}
\hline Seaweeds & \multicolumn{4}{|c|}{ Mortality (\%) in various concentrations } \\
\hline & $100 \mu \mathrm{g} / \mathrm{ml}$ & $200 \mu \mathrm{g} / \mathrm{ml}$ & $300 \mu \mathrm{g} / \mathrm{ml}$ & $400 \mu \mathrm{g} / \mathrm{ml}$ \\
\hline V. pachynema & $8 \pm 2.03$ & $49 \pm 3.6$ & $96.66 \pm 5.77$ & $100 \pm 0.0$ \\
\hline C. antennina & 0 & $27.6 \pm 3.2$ & $91.66 \pm 2.88$ & $100 \pm 0.0$ \\
\hline E. intestanalis & $6.1 \pm 2.4$ & $43 \pm 4.42$ & $100 \pm 0.0$ & $100 \pm 0.0$ \\
\hline A. orientalis & $14.33 \pm 4.5$ & $100 \pm 0.0$ & $100 \pm 0.0$ & $100 \pm 0.0$ \\
\hline U. fasciata & $5.8 \pm 2.1$ & $32.4 \pm 6.3$ & $84.33 \pm 4.04$ & $100 \pm 0.0$ \\
\hline C. racemosa & $7 \pm 1.6$ & $38.6 \pm 3.7$ & 1000.0 & $100 \pm 0.0$ \\
\hline D. dichotoma & 0 & $20 \pm 1.54$ & $89.33 \pm 3.05$ & $100 \pm 0.0$ \\
\hline P. tetrastromatica & 0 & $14.33 \pm 4.04$ & $85.66 \pm 5.5$ & $100 \pm 0.0$ \\
\hline C. bicanaliculata & 0 & $16 \pm 4.21$ & $53 \pm 3.21$ & $100 \pm 0.0$ \\
\hline G. corticata & 0 & $26 \pm 6.0$ & $67.66 \pm 6.8$ & $100 \pm 0.0$ \\
\hline H. pannosa & 0 & $25.33 \pm 5.03$ & $86 \pm 4.0$ & $100 \pm 0.0$ \\
\hline C. clavulatum & 0 & $22.1 \pm 2.6$ & $95.66 \pm 4.04$ & $100 \pm 0.0$ \\
\hline C. spectabile & 0 & $11.2 \pm 3.8$ & $40 \pm 5.0$ & $100 \pm 0.0$ \\
\hline Control + & 0 & 0 & 0 & 0 \\
\hline Control - & 0 & 0 & 0 & 0 \\
\hline . & 0 & & & \\
\hline
\end{tabular}

Mean \pm SD $n=6$ experiments

Table 3. Nematicidal activity of seaweeds.

\begin{tabular}{|c|c|c|c|c|}
\hline \multirow{2}{*}{ Seaweeds } & \multicolumn{4}{|c|}{ Mortality $(\%)$ in various concentrations } \\
\hline & $1 \mathrm{mg} / \mathrm{ml}$ & $2 \mathrm{mg} / \mathrm{ml}$ & $3 \mathrm{mg} / \mathrm{ml}$ & $4 \mathrm{mg} / \mathrm{ml}$ \\
\hline$V \cdot$ pachynema & $8 \pm 3.87$ & $31 \pm 8.54$ & $60 \pm 3.60$ & $100 \pm 0.0$ \\
\hline C. antennina & $12 \pm 6.08$ & $32.33 \pm 9.29$ & $100 \pm 0.0$ & $100 \pm 0.0$ \\
\hline E. intestanalis & $26 \pm 4.13$ & $70.3 \pm 9.5$ & $100 \pm 0.0$ & $100 \pm 0.0$ \\
\hline A.. orientalis & $18 \pm 1.24$ & $80.33 \pm 1.52$ & $100 \pm 0.0$ & $100 \pm 0.0$ \\
\hline U. fasciata & $14.3 \pm 3.14$ & $75.33 \pm 4.5$ & $86 \pm 2.31$ & $100 \pm 0.0$ \\
\hline C. racemosa & $15 \pm 4.52$ & $44.33 \pm 6.02$ & $88 \pm 5.42$ & $100 \pm 0.0$ \\
\hline D. dichotoma & $36.4 \pm 5.13$ & $100 \pm 0.0$ & $100 \pm 0.0$ & $100 \pm 0.0$ \\
\hline $\begin{array}{c}P . \\
\text { tetrastromatica }\end{array}$ & $10 \pm 3.14$ & $60 \pm 5.29$ & $66 \pm 1.08$ & $100 \pm 0.0$ \\
\hline C. bicanaliculata & $28 \pm 2.8$ & $56 \pm 6.17$ & $76 \pm 3.91$ & $100 \pm 0.0$ \\
\hline G. corticata & $21.2 \pm 1.38$ & $58.66 \pm 8.08$ & $100 \pm 0.0$ & $100 \pm 0.0$ \\
\hline H. pannosa & $38.7 \pm 6.07$ & $100 \pm 0.0$ & $100 \pm 0.0$ & $100 \pm 0.0$ \\
\hline C. clavulatum & $14.2 \pm 5.27$ & $56 \pm 5.29$ & $92 \pm 2.98$ & $100 \pm 0.0$ \\
\hline C. spectabile & $6.2 \pm 1.24$ & $43 \pm 6.08$ & $91 \pm 1.78$ & $100 \pm 0.0$ \\
\hline Control + & 0 & 0 & 0 & 0 \\
\hline Control - & 0 & 0 & 0 & 0 \\
\hline
\end{tabular}

dichotoma was considered as extremely toxic since $100 \%$ mortality was observed even at lowest test concentration (50 $\mu \mathrm{g} / \mathrm{ml})$. D. dichotoma has been early reported to have an- tifeedant activity [52]. This extreme toxicity could be attributed to the existence of complex mixtures of terpenoids, acetogenins and aromatic terpenes synthesized by marine algae Dictotales $[11,39]$. Some of these compounds are effective deterrents, preventing the algal consumption [20]. In the present study, $E$. intestinalis, $H$, pannosa, $C$. racemosa and $C$. spectabile were moderately toxic and all other five species showed low toxicity (Table 4). It was found that all the extracts impart same sort of behavioral changes. In the initial stages, fingerlings showed rapid movement with high stress and surface gasping, slow swimming while in advance stages showed occasional paralysis and inclined to the bottom in an inverted posture (Table 5).

Antipredation is an index of ecological potential against herbivory. Seaweeds were considered as one of the highly selective feed of herbivorous fishes. Herbivory is a prominent threat in the cultivation of seaweeds in open sea. Marine algae are well known for their chemical defense mechanism against herbivory [36]. According to Norris and Fenical [32] bioactive natural product of seaweeds are evolved due to high grazing pressure of herbivory. Van et al. [54] reported that substantial spatial variation in concentrations of metabolites thought to have antifeedant properties. The potent secondary metabolites in seaweeds and their lower consumption by hebivory are an index of algal-herbivory interactions [46, 19]. The chemical defense mechanism of the algae can be potentially useful to humans in the form of natural antibiotics and UV-sunscreens [45]. Based on the present findings it could be inferred that seaweed, D. dichotoma can reduce the grazing pressure by herbivorous fishes and this antifeedant defense mechanism makes it a potential candidate for the development of eco-friendly ichthyocides.

\section{Larvicidal Activity}

Data obtained from the larvicidal activity of seaweed extracts at the end of $24 \mathrm{~h}$ suggested that second instar larvae were highly sensitive than third instar. Of the 13 seaweed extracts studied A. orientalis, $P$. tetrastromatica and $C$. clavulatum were most effective against second instar larvae and having $\mathrm{LD}_{50}$ value of 91,96 and $97 \mu \mathrm{g} / \mathrm{ml}$ respectively (Table 6). However, a lower level of activity was observed in Chnoospora bicanaliculata, D. dichotoma, C. spectabile and G. corticata (LD 50 value $245,226,223$ and $220 \mu \mathrm{g} / \mathrm{ml})$. In third instar larvicidal assay, secondary metabolities of $A$. orientalis, $C$. racemosa and C. clavulatum were found to be highly lethal $\left(\mathrm{LD}_{50}\right.$ value 158 , 194 and $199 \mu \mathrm{g} / \mathrm{ml}$ ) whereas G. corticata and C. bicanaliculata having less lethality $\left(\mathrm{LD}_{50}\right.$ value 446 and $389 \mu \mathrm{g} / \mathrm{ml}$ ). The present study revealed that $A$. orientalis contained potential mosquito control principles and can be used for the development of biocontrol tactics.

Mosquito are the vector for large number of human pathogens than any other group of arthropods [17, 5]. Their uncontrollable breeding is posing a serious threat to the modern humanity. Every year more than 500 million people become severely affected with malaria. Many plant derived natural compounds were tested for mosquito control [6]. Early report envisages that marine plant extracts contain promising larvicidal activity [48, 
Table 4. Ichthyotoxicity of seaweeds.

\begin{tabular}{|c|c|c|c|c|c|c|c|c|c|}
\hline \multirow[b]{2}{*}{ Seaweeds } & \multicolumn{7}{|c|}{ Mortality (\%) in various concentrations } & \multirow{2}{*}{$\begin{array}{l}\text { Time }(\mathrm{h}) * \\
\text { for } 100 \% \\
\text { mortality }\end{array}$} & \multirow[b]{2}{*}{ Toxicity } \\
\hline & $25 \mu \mathrm{g} / \mathrm{ml}$ & $50 \mu \mathrm{g} / \mathrm{ml}$ & $100 \mu \mathrm{g} / \mathrm{ml}$ & $150 \mu \mathrm{g} / \mathrm{ml}$ & $200 \mu \mathrm{g} / \mathrm{ml}$ & $250 \mu \mathrm{g} / \mathrm{ml}$ & $300 \mu \mathrm{g} / \mathrm{ml}$ & & \\
\hline V. pachynema & 0 & $47.2 \pm 2.23$ & $100 \pm 0.0$ & $100 \pm 0.0$ & $100 \pm 0.0$ & $100 \pm 0.0$ & $100 \pm 0.0$ & 2 & HT \\
\hline C. antennina & 0 & 0 & 0 & 0 & $23 \pm 2.76$ & $55.3 \pm 1.8$ & $100 \pm 0.0$ & 6 & LT \\
\hline E. intestanalis & 0 & 0 & 0 & $20.3 \pm 4.5$ & $80 \pm 7.2$ & $100 \pm 0.0$ & $100 \pm 0.0$ & 3 & MT \\
\hline A. orientalis & 0 & $65 \pm 5.6$ & $100 \pm 0.0$ & $100 \pm 0.0$ & $100 \pm 0.0$ & $100 \pm 0.0$ & $100 \pm 0.0$ & 2 & HT \\
\hline U. fasciata & 0 & 0 & 0 & $10.5 \pm 4.11$ & $43 \pm 1.3$ & $100 \pm 0.0$ & $100 \pm 0.0$ & 6 & LT \\
\hline C. racemosa & 0 & $43 \pm 2.33$ & $100 \pm 0.0$ & $100 \pm 0.0$ & $100 \pm 0.0$ & $100 \pm 0.0$ & $100 \pm 0.0$ & 3 & MT \\
\hline D. dichotoma & $40 \pm 6.11$ & $100 \pm 0.0$ & $100 \pm 0.0$ & $100 \pm 0.0$ & $100 \pm 0.0$ & $100 \pm 0.0$ & $100 \pm 0.0$ & 2 & HT \\
\hline P. tetrastromatica & 0 & 0 & $22.3 \pm 3.17$ & $100 \pm 0.0$ & $100 \pm 0.0$ & $100 \pm 0.0$ & $100 \pm 0.0$ & 6 & $\mathrm{LT}$ \\
\hline C. bicanaliculata & 0 & 0 & 0 & 0 & 0 & $27 \pm 5.9$ & $100 \pm 0.0$ & 6 & LT \\
\hline G. corticata & 0 & 0 & 0 & 0 & $10.6 \pm 2.4$ & $41.26 \pm 1.9$ & $100 \pm 0.0$ & 6 & LT \\
\hline H. pannosa & 0 & 0 & 0 & $16.12 \pm 2.1$ & $30 \pm 1.5$ & $100 \pm 0.0$ & $100 \pm 0.0$ & 3 & MT \\
\hline C. clavulatum & 0 & 0 & 0 & 0 & $24 \pm 8.5$ & $37 \pm 1.2$ & $100 \pm 0.0$ & 6 & LT \\
\hline C. spectabile & 0 & $31 \pm 7.2$ & $100 \pm 0.0$ & $100 \pm 0.0$ & $100 \pm 0.0$ & $100 \pm 0.0$ & $100 \pm 0.0$ & 3 & MT \\
\hline Control + & 0 & 0 & 0 & 0 & 0 & 0 & 0 & - & - \\
\hline
\end{tabular}

*Onset time of $100 \%$ mortality at lowest lethal concentration.

HT=highly toxic, MT=medium toxic, LT=low toxic.

Table 5. Behavioral changes observed in D. aequipinnatus after algal extract treatment.

\begin{tabular}{|l|l|}
\hline Stages & Behavioral changes \\
\hline Stage 1 & $\begin{array}{l}\text { Rapid movement with high stress } \\
\text { Surface gasping }\end{array}$ \\
\hline Stage 2 & $\begin{array}{l}\text { Slow swimming } \\
\text { Violent movement of gill chambers }\end{array}$ \\
\hline Stage 3 & $\begin{array}{l}\text { Loose of equilibrium } \\
\text { Occasional paralysis }\end{array}$ \\
\hline Stage 4 & Inverted posture and mortality \\
\hline
\end{tabular}

49]. Watanabe et al. [56] found that polyhalogenated monoterpenes, aplysiaterpenoid A and telfairine isolated from Plocamium $s p$. showed insecticidal activity against mosquito larvae. Ishibashi et al. [24] reported the extracts of Aglaia elliptifolia showed insecticidal activity. Application of larvicides in their breeding places is a successful way to control its density.

In the present study, the green alga $A$. orientalis was highly bioactive seaweed among the tested taxa. Seaweeds are taxonomically heterogeneous group of organisms, which is commonly classified into three divisions according to their primary or secondary photosynthetic pigments. There is considerable ecological and physiological variation among different species within these three divisions, including production of bioactive secondary metabolites that may function to deter herbivory [29]. Epiphytic bacterial assemblages of seaweeds tested for bioactivity indicated that the green alga $A$. orientalis harboured antagonistic heterotrophic biofilm (epiphytic) bacterium Marinobacter sp. EB5 (data not shown). Therefore the highest bioactivity associated with the green alga $A$. orientalis may be due to two possible reasons/ phenomenon (i) the epiphytic antagonistic producer Marinobacter sp. EB5 might have sequestrated antibacterial substances on the surface biofilm layer which ultimately increase of bioactivity profile of $A$. orientalis or (ii) the host seaweed itself might produce antibacterial substances against fouling/predatory pressure in the habitat.

\section{CONCLUSION}

From the present study, it can be concluded that the potency of the marine alga $A$. orientalis was very high which exhibited a wide range of activity in brine shrimp cytotoxicity, antifeedant and larvicidal bioassays whereas the extracts of $D$. dichotoma showed significant activity against herbivorous fishes and nematodes. The extracts of $H$. pannosa was effective to nematodes and second instar larvae. Therefore, the seaweed $H$. pannosa might be a potential source for developing ecologically significant bioactive compounds including biodegradable pesticides, and biopharmaceuticals. 
Table 6. Larvicidal potential of seaweeds against second and third instar larvae of Culex sp.

\begin{tabular}{|c|c|c|c|c|c|c|c|c|c|c|}
\hline \multirow{3}{*}{ Seaweeds } & \multicolumn{10}{|c|}{ Mortality $(\%)$ in various concentrations } \\
\hline & \multicolumn{2}{|c|}{$100 \mu \mathrm{g} / \mathrm{ml}$} & \multicolumn{2}{|c|}{$200 \mu \mathrm{g} / \mathrm{ml}$} & \multicolumn{2}{|c|}{$300 \mu \mathrm{g} / \mathrm{ml}$} & \multicolumn{2}{|c|}{$400 \mu \mathrm{g} / \mathrm{ml}$} & \multicolumn{2}{|c|}{$500 \mu \mathrm{g} / \mathrm{ml}$} \\
\hline & 2 instar & 3 instar & 2 instar & 3 instar & 2 instar & 3 instar & 2instar & 3 instar & 2 instar & 3 instar \\
\hline V. pachynema & $28.1 \pm 5.03$ & 0 & $100 \pm 0.0$ & 0 & $100 \pm 0.0$ & $25.23 \pm 8.12$ & $100 \pm 0.0$ & $75.2 \pm 2.31$ & $100 \pm 0.0$ & $100 \pm 0.0$ \\
\hline C. antennina & $47.5 \pm 1.83$ & 0 & $100 \pm 0.0$ & 0 & $100 \pm 0.0$ & 0 & $100 \pm 0.0$ & $69.6 \pm 4.04$ & $100 \pm 0.0$ & $100 \pm 0.0$ \\
\hline E. intestanalis & $53.4 \pm 2.17$ & 0 & $100 \pm 0.0$ & $46.7 \pm 4.83$ & $100 \pm 0.0$ & $88.8 \pm 1.13$ & $100 \pm 0.0$ & $100 \pm 0.0$ & $100 \pm 0.0$ & $100 \pm 0.0$ \\
\hline A. orientalis & $62.6 \pm 3.8$ & 0 & $100 \pm 0.0$ & $81.8 \pm 4.18$ & $100 \pm 0.0$ & $100 \pm 0.0$ & $100 \pm 0.0$ & $100 \pm 0.0$ & $100 \pm 0.0$ & $100 \pm 0.0$ \\
\hline U. fasciata & $38.2 \pm 6.07$ & 0 & $100 \pm 0.0$ & 0 & $100 \pm 0.0$ & $37.3 \pm 4.32$ & $100 \pm 0.0$ & $100 \pm 0.0$ & $100 \pm 0.0$ & $100 \pm 0.0$ \\
\hline C. racemosa & $33.02 \pm 1.23$ & $21.2 \pm 3.2$ & $96.01 \pm 2.75$ & $57.14 \pm 2.8$ & $100 \pm 0.0$ & $67.6 \pm 4.63$ & $100 \pm 0.0$ & $100 \pm 0.0$ & $100 \pm 0.0$ & $100 \pm 0.0$ \\
\hline D. dichotoma & 0 & 0 & $36.09 \pm 8.62$ & $13.2 \pm 2.31$ & $100 \pm 0.0$ & $35.12 \pm 4.03$ & $100 \pm 0.0$ & $81.3 \pm 1.26$ & $100 \pm 0.0$ & $100 \pm 0.0$ \\
\hline P. tetrastromatica & $57.3 \pm 3.18$ & 0 & $100 \pm 0.0$ & $16.6 \pm 3.84$ & $100 \pm 0.0$ & $75.5 \pm 5.0$ & $100 \pm 0.0$ & $100 \pm 0.0$ & $100 \pm 0.0$ & $100 \pm 0.0$ \\
\hline C. bicanaliculata & 0 & 0 & $28.65 \pm 5.87$ & 0 & $83.43 \pm 4.87$ & $18 \pm 1.2$ & $100 \pm 0.0$ & $62.5 \pm 6.12$ & $100 \pm 0.0$ & $100 \pm 0.0$ \\
\hline G. corticata & 0 & 0 & $23.7 \pm 4.87$ & 0 & $100 \pm 0.0$ & $7.2 \pm 2.5$ & $100 \pm 0.0$ & $29.6 \pm 3.78$ & $100 \pm 0.0$ & $100 \pm 0.0$ \\
\hline H. pannosa & $43.4 \pm 6.03$ & $6.2 \pm 2.12$ & $100 \pm 0.0$ & $33.33 \pm 6.25$ & $100 \pm 0.0$ & $100 \pm 0.0$ & $100 \pm 0.0$ & $100 \pm 0.0$ & $100 \pm 0.0$ & $100 \pm 0.0$ \\
\hline C. clavulatum & $58.3 \pm 4.91$ & $23.2 \pm 3.4$ & $100 \pm 0.0$ & $66.6 \pm 3.96$ & $100 \pm 0.0$ & $83.4 \pm 3.16$ & $100 \pm 0.0$ & $100 \pm 0.0$ & $100 \pm 0.0$ & $100 \pm 0.0$ \\
\hline C. spectabile & $43.1 \pm 8.31$ & 0 & $100 \pm 0.0$ & $33.4 \pm 6.25$ & $100 \pm 0.0$ & $50.4 \pm 1.56$ & $100 \pm 0.0$ & $100 \pm 0.0$ & $100 \pm 0.0$ & $100 \pm 0.0$ \\
\hline Control + & 0 & 0 & 0 & 0 & 0 & 0 & 0 & 0 & 0 & 0 \\
\hline Control - & 0 & 0 & 0 & 0 & 0 & 0 & 0 & 0 & 0 & 0 \\
\hline
\end{tabular}

Mean \pm SD $n=6$ experiment

\section{ACKNOWLEDGEMENTS}

We wish to thank Dr. A. P. Lipton, Professor and Head, Department of Marine Biotectnology, CMST, Rajakkamagalam, Nagercoil for valuable suggestions throughout this study. Thanks are extending to Dr. M. V. N. Panikkar, Dr. Priyadharsan D. Prasad, R. Rajagopal, Dr. S. Sulekha, C. K. Thankachy and Dr. M. Jayakumari Professors, Department of Biotechnology, Botany and Zoology, Sree Narayana College, Kollam, Kerala for encouragements. The first author AM and SS is gratefully acknowledged to DBT for providing JRF. This paper is a part of the DBT project (BT/PR8064/AAQ/03/290/2006).

\section{REFERENCES}

1. Abid, M., Sultana, V., Zaik, M. J., and Maqbool, M. A., "Nematicidal properties of Stoechospermum marginatum, a seaweed," Pakistan Journal of Phytopathology, Vol. 9, pp. 143-147 (1997).

2. Aliya, R. and Shamaeel, M., "Phytochemical evaluation of four coenocytic green seaweeds from the coast of Karachi," Pakistan Journal of Marine Biology (Mar. Res.), Vol. 5, pp. 65-76 (1999).

3. Ara, J., Sultana, V., Ehteshamul-Haque, S., and Ahmad, Q. R. V. U., "Cytotoxic activity of marine macroalgae on Atremia salina (brine shrimp)," Phytotherapy Research, Vol. 13, pp. 304-307 (1999).

4. Barbier, P., Guise, S., Huitorel, P., Amade, P., Pesando, D., Briand, C., and Peyrot, V., "Caulerpenyne from Caulerpa taxifolia has an antiproliferative activity ontumour cell line SK-N-SH and modifies the microtubule network," Life Science, Vol. 70, pp. 415-429 (2001).

5. Cepleanu, F., Validation and Application of Three Bench-Top Bioassays for Screening of Crude Extracts and Subsequent Activity-Guided Isolation, $\mathrm{PhD}$ thesis, Facultedes Sciences, Universite de Lausanne, Lausanne,
(1993).

6. Consoli, R. A. and Oliveira, R. L., "Principais mosquitos de importancia sanitaria no Brasil," Fiocruz, Rio de Janeiro, pp. 225 (1994).

7. Coombe, D. R., Parish, C. R., Ramshaw, I. E., and Snowden, J. M., "Analysis of the inhibition of tumour metastasis by sulphated polysaccharides," International Journal of Cancer, Vol. 39, pp. 82-88 (1987).

8. Crouch, I. J. and Van Staden, J., "Effect of seaweed concentrate from Ecklonia maxima (Osbeck) papenfuss on Meloidogyne incognita infection on tomato," Journal of Applied Phycology Vol. 5, pp. 37-43 (1993).

9. Culioli, G., Daoudi, M., Ortalo-Magne, A., and Piovetti, V.R.L., "(S)-12 hydroxygeranylgeraniol-derived dipterpenes from the brown alga Bifurcaria bifurcate," Phytochemistry, Vol. 57, pp. 529-535 (2001).

10. Dhargalkar, V. K. and Neelam, P., "Seaweed: promising plant of the millennium," Science and Culture, Vol. 71, pp. 60-66 (2005).

11. Faulkner, D. J., "Marine natural products," Natural Product Reports, Vol. 19, pp. 1-48 (1986).

12. Faulkner, D. J., "Marine natural products," Natural Product Reports, Vol. 18, pp. 1-49 ( 2001).

13. Featonby-Smith, B. C. and Van Staden, J., "The effect of seaweed concentrate on the growth of tomato plant in nematode infested soil," Scientia Horticulturae, Vol. 20, pp. 137-146 (1983).

14. Fischel, J. L., Lemee, R., Formento, P., Caldani, C., Moll, J. L., Pesando, D., Meinesz, A., Grelier, P., Peitra, F., Guerriero, A., and Milano, G., "Cell growth inhibitory effects of caulerpenyne, a sesquiterpenoid from the marine algae Caulerpa taxifolia," Anticancer Research, Vol. 15, pp. 2155-2160 (1995).

15. Garg, H. S., Sharma, T., Bhakuni, D. S., Pramanik, B. N., and Bose, A. K., "An antiviral sphingosine derivative from green alga Ulva fasiata," Tetrahedron Letters, Vol. 33, pp. 1641-1644 (1992).

16. Gerwick, W. H. and Fenical, W., "Ichthyotoxic and cytotoxic metabolites of thetropical brown alga Stypopodium zonale," Journal of Organic Chemistry, Vol. 46, pp. 21-27(1981).

17. El-Hag, E. A., Nadi, A. H., and Zaitoon, A. A., "Toxic and growth retarding effects of three plant extracts on Culex pipiens larvae (Diptera: culicidae)," Phytotherapy Research, Vol. 13, pp. 388-392 (1999). 
18. Harder, R. and Oppermann, A., "Uber Antibiotische Stoffe bie den Grunalgen Stichoccus bacillaris and Protosiphon bomyoides," Archives of Microbiology, Vol. 19, pp. 398-401 (1953).

19. Hay, M. E., Lee, J. R., Guieb, R. R., and Bennett, M. M., "Food preference and Chemotasis in the sea urchin Arbacia punctulata (Lamarck) Philippi," Journal of Experimental Marine Biology and Ecology, Vol. 96, pp 147-153 (1986)

20. Hay, M. E., Paul, V. J., Lewis, S. M., Gustafson, K., and Tucker, J., "Can tropical seaweed reduce herbivory by growing at night? Diel patterns of growth, nitrogen content, herbivory and chemical versus morphological defenses," Oecologia, Vol. 75, pp. 233-245 (1988).

21. Hay, M. E., "Marine chemical ecology: What is known and what is next?" Journal of Experimental Marine Biology and Ecology, Vol. 200, pp. 103-134 (1996).

22. Higa, T. and Kuniyoshi, M., "Toxins associated with medicinal and edible seaweeds," Journal of Toxicology-Toxin Reviews, Vol. 19, pp. 119-137 (2000).

23. Huang, X., Zhoui, H., and Zhang, H., "The effect of Sargassum fusiforme polysaccharide extracts on vibriosis resistance and immune activity of the shrimp Fenneropenaeus chinensis," Fish and Shellfish Immunology, Vol 20, pp. 750-757 (2005).

24. Ishibashi, F., Satasook, C., Isman, M. B., Towers, N. G. H., "Insecticidal 1HCyclopentatetrahydro[b] Benzofurans from Aglaia odorata," Phytochemistry, Vol. 32, pp. 307-310 (1993)

25. Jacobs, R. S., Culver, P., Langdon, R., O’Brien, T., and White, S., "Some pharmacological observation on marine natural products," Tetrahedron Letters, Vol. 41, pp. 981-984 (1985).

26. Lourdu Mariadoss, K., Studies on Extraction, Isolation and Characterization of Bioactive Compounds From Seaweeds and Their Effect on Bacterial Blight of Rice Caused by Xanthomonas Oryzae P.V Oryzae (Ishiyama) Dye, Ph.D thesis University of Madras, Chennai (1998).

27. Lucas, G. B., Lucas. L. T., and Campbell, L. C., Introduction to plant Diseases: Identification and Management, 2nd Ed., AVI Publishing Company, Inc., pp. 313 (1985).

28. Mantri, V. A., "Seaweed floristic studies along tsunami affected Indian coasts: a litmus test scenario after 26th December 2004," Journal of Earth System Science, Vol. 115, pp. 371-378 (2006).

29. McClintock, J. B. and Baker, B. J., Marine Chemical Ecology, CRC Press, Boca Raton, FL (2001).

30. Meyer, B. N., Ferrigni, N. R., Putnam, G. E., Jacobsen, L. B., Nichols, D. E., and McLaughlin, J.L., "Brine shrimp: a convenient general bioassay for active plant constituents," Planta Medica, Vol. 45, pp. 31-34 (1982).

31. Munro, M. H. G. and Blunt, J. W., Marinlit, version 10.4, Marine Chemical Group, University of Canterbury, Christchurch, New Zealand (1999).

32. Norris, J. N. and Fenical, W., "Chemical defense in tropical marine algae," in: Rutzler, K. and Maclntyre, I. G. (eds), Atlantic Barrier Reef Ecosystem Carrie Bow Cay, Belize, Scientific Report 1: Structure and Communities, Smithson Contr. Marine Science, Vol. 12, pp. 417-431 (1982).

33. Oza, R. M. and Zaidi, S. H., A Revised Checklist of Indian Marine Algae Central Salt and Marine Chemicals Research Institute, Bhavanagar, India pp. 296 (2000).

34. Palermo, J. A., Flower, B. P., and Seldes, A. M., "Chondriamides A and B new indolic metabolities from red algae Chondria sp," Tetrahedron Letters, Vol. 33, pp. 3097-3100 (1992).

35. Parent-Massin, D., Fournier, V., Amade, P., Lemee, R., Durand-Clement, M., Delescluse, C., and Presando, D., "Evaluation of toxicological risk to humans of caulerpenyne using human hematopoietic progenitors, melanocytes and keratinocyctes in culture," Journal of Toxicology and Environmental Health, Vol. 47, pp. 47-59 (1996).

36. Pavia, H. and Toth, G. B., "Inducible chemical resistance to herbivory in the brown seaweed Ascophyllum nodosum," Ecology, Vol. 81, pp 3212-3225 (2000)

37. Pratt, R., Daniel, T. C., Gunnison, J. B., Kumler, W. D., Oneto, J. F., Strait, L. A., Spoehr, H. A., Hardin, G. J., Milner, H. W., Smith, J. H. C., and
Strain, H. H., "Chlorellin: an antibacterial substances from Chlorella," Science, Vol. 99, pp. 351-352 (1944)

38. Religa, P., Kazi, M., Thyberg, J., Gaciong, Z., Swedenborg, J., and Hedin, U., "Fucoidan inhibits smooth muscle cell proliferation and reduces mitogen activated protein kinase activity," European Journal of Vascular and Endovascular Surgery, Vol. 20, pp. 419-426 (2000).

39. Ruffolo, R. R., Rooks, D. P. (jr.)., Hoffman, W. F., and Poste, G., Drug News and Perspectives, Vol. 4, pp. 217 (1991)

40. Sahoo, D., Sahu, N., and Sahoo, D., Seaweeds of Indian Coast, New Delhi: A. P. H. Publishing Corporation, pp. 283 (2001).

41. Sasser, J. N., "Root-knot nematodes: a global menace to crop production," Plant Disease, Vol. 64, pp. 36-41 (1980).

42. Selvin, J. and Lipton, A. P., "Biopotentials of Ulva fasciata and Hypnea musiformis collected from the peninsular coast of India," Journal of Marine Science and Technology, Vol. 12, pp. 1-6 (2004).

43. Serkedjieva, J., "Antiviral activity of the red marine algae Ceramium rubrum,” Phytotherapy Research, Vol. 18, pp. 480-483 (2004).

44. Silva, P. C., Barson, P. W., and Moe, R. L., Catalogue of the Benthic Marine Algae of the Indian Ocean, University of California (1996)

45. Smith, A. J., "Medicinal and pharmaceutical uses of seaweed natural products: a review," Journal of Applied Phycology, Vol. 16, pp. 245-262 (2004).

46. Steinberg, P. D., "Chemical defenses and susceptibility of tropical marine brown algae to Herbivores," Oecologia, Vol. 69, pp. 628-630 (1986)

47. Tang, H. F., Yi, Y. H., Yao, X. S., Xu, Q. Z., Zhang, S. Y., and Lin, H. W., "Bioactive steroids from the brown algae Sargassum carpophyllum," Journal of Asian Natural Product Research, Vol. 4, pp. 95-105 (2002).

48. Thangam, T. S. and Kathiresan. K., "Mosquito larvicidal activity of marine plant extracts with synthetic insecticides," Botanica Marina, Vol. 34 , pp. 537-539 (1991)

49. Thangam, T. S., Kathiresan, K., and Mabbett, T., "Mosquito larvicidal activity of seaweed extract against Aedes aegypti and Culex quinquefasciatus," International Pest Control, Vol. 35, pp. 94-95 (1993).

50. Tuney, I., Cadirci, B. H., Unal, D., and Sukatar, A., "Antimicrobial activities of the extracts of marine algae from the coast of Urla (Izmir, Turkey)," Turkish Journal of Biology, Vol. 30, pp. 171-175 (2006).

51. Urones, J. G., Basabe, P., Marcos, I. S., Pineda, J., Lithgow, A. M., Moro, R. F., Brito Palma, F. M. S., Araujo, M. E. M., and Gravalos, M. D. G., "Meroterpenes from Cystoseira usneoides," Phytochemistry, Vol. 31, pp. 179-182 (1992).

52. Valerie, J. P. and Hay, M. E., "Seaweed susceptibility to herbivory," Chemical and Morphology Correlates," Marine Ecology-Progress Series, Vol. 33, pp. 255-264 (1986)

53. Valls, R., Piovetti, L., Banaigs, B., Archavlis, A., and Pellegrini, M., "(S) 13- hydroxygeranylgeraniol-derived furanoditerpenes from Bifurcaria bifurcate," Phytochemistry, Vol. 39, pp. 145-149 (1995).

54. Van Alstyne, K. L., Duggins, D. O., and Dethier, M. N., "Spatial patterns in macroalgal chemical defenses," in: McClintock, J. B., and Baker, B. J. Ed., Marine Chemical Ecology, CRC Press, Boca Raton, pp. 301-324 (2001).

55. Wardlaw, A. C., Practical Statistics for Experimental Biologists, John Wiley and Sons, Chichester (1985).

56. Watanabe, K., Miyakado, M., Ohno, N., Okada, A., Yanagi, K., and Moriguchi, K., "A polyhalogenated insecticidal monoterpene from the red alga, Plocamium telfairiae," Phytochemistry, Vol. 28, pp. 77-78 (1989).

57. Whapman, C. A., Jenkins, T., Blunden, G., and Hankins, S.D., "The role of seaweed extracts, Ascophyllum nodosum, in the reduction in fecundity of Meloidogyne javanica," Fundamental and Applied Nematology, Vol. 17, pp. 181-183 (1994)

58. Wu, Y., Jenkins, T., Blunden, G., Whapham, C., and Hankins, S.D., "The role of betaines in alkaline extracts of Ascophyllum nodosum in the reduction of Meloidogyne javanica and M. incognita infestation of tomato plants," Fundamental and Applied Nematology, Vol. 20, pp. 99-102 (1997). 